ljtihad, Jurnal Wacana Hukum Islam dan Kemanusiaan

Vol. 16, No. 2 (2016), pp. 159-177, doi : 10.18326/ijtihad.v16i2.159-177

\title{
Perlindungan hukum terhadap harta benda wakaf sebagai aset publik di kecamatan Wiradesa kabupaten Pekalongan
}

\author{
Achmad Irwan Hamzani dan Mukhidin \\ Fakultas Hukum dan Pascasarjana Universitas Pancasakti Tegal \\ E-mail:achmad_irwahz@yahoo.co.id \\ DOI:10.18326/ijtihad.v16i2.159-177
}

\begin{abstract}
The treasure of the waqf is a public asset that should be protected by law. Waqf is a legal act that its implementation must be in accordance with statutory procedures. Mandatory legal act waqf deed pledges poured in endowments. But in practice there is still a committed implementation of the waqf not according to legal procedures. Implementation of the waqf is not stated in the Deed of Pledge Waqf as happened in the district Wiradesa Pekalongan thus has no legal force. Departing from this fact research is needed to describe the implementation of endowments in the District Wiradesa and formulate legal safeguards against waqf property as a public asset in the District Wiradesa. This research is a field research. The approach is sociological, thus falling within the scope of empirical legal research. The collection of data through observation and interviews. Data were analyzed using the model of induction-interpretation. The results showed that the waqf property in District Wiradesa many do not have authentic proof recognized by the law. Necessary legal means to protect the property of the waqf of potential irregularities.
\end{abstract}

Harta benda wakaf merupakan aset publik yang harus dilindungi secara hukum. Wakaf merupakan perbuatan hukum yang pelaksanannya harus sesuai dengan prosedur perundang-undangan. Perbuatan hukum wakaf wajib dituangkan dalam akta ikrar wakaf. Namun dalam praktek masih terdapat pelaksanaan wakaf yang dilakukan tidak sesuai prosedur hukum. Pelaksanaan wakaf tidak dituangkan dalam Akta Ikrar Wakaf seperti yang terjadi di Kecamatan Wiradesa Kabupaten Pekalongan sehingga tidak memiliki kekuatan hukum. Berangkat dari fakta inilah diperlukan penelitian untuk mendeskripsikan pelaksanaan wakaf di Kecamatan Wiradesa dan merumuskan upaya perlindungan hukum terhadap harta benda wakaf sebagai aset publik di Kecamatan Wiradesa. Jenis penelitian ini adalah penelitian lapangan. Pendekatannya sosiologis, sehingga termasuk dalam lingkup penelitian hukum empiris. Pengumpulan data melalui observasi dan wawancara. Data dianalisis menggunakan model induksi-itepretasi. Hasil 
penelitian menunjukkan bahwa harta benda wakaf di Kecamatan Wiradesa banyak yang tidak memiliki bukti otentik yang diakui oleh hukum. Diperlukan sarana hukum untuk melindungi harta benda wakaf dari potensi penyimpangan.

\section{Keywords: Protection; Law; Waqf; Public asset}

\section{Pendahuluan}

Wakaf merupakan amalan dalam ajaran Islam yang memiliki dimensi spiritual dan sosial. Dimensi spiritual karena wakaf merupakan doktrin agama yang bermotif pahala (kebaikan di akhirat). Sedangkan dimensi sosial karena pemberian wakaf berdampak pada kesejahteraan sosial dan ekonomi. Harta benda wakaf memiliki fungsi sosial yang tinggi dan sangat berharga dalam pembangunan (Fikri dan Noor, 2012: 44).

Harta benda yang telah diwakafkan oleh pemiliknya menjadi milik umat atau aset publik. Sebagai aset publik wakaf harus dilindungi secara hukum agar terhindar dari penyelewengan seperti beralih menjadi aset pribadi. Berbagai peraturan perundangan telah dibuat oleh Pemerintah Indonesia untuk memberikan perlindungan hukum terhadap wakaf.

Menurut hukum Islam, wakaf memang telah terjadi seketika dengan adanya pernyataan wakif (orang yang wakaf) yang merupakan ijab, karena pelaksanaan wakaf dipandang sebagai perbuatan hukum sepihak (Hamzani, 2015: 72). Namun untuk menjamin kepastian hukum di Indonesia, mengharuskan wakaf dilakukan secara lisan dan tertulis di hadapan Pejabat Pembuat Akta Ikrar Wakaf (PPAIW), dibuatkan Akta Ikrar Wakaf (AIW), didaftarkan, disertifikasi, dan diumumkan ke publik. Apabila benda wakaf berupa tanah milik, dengan mendasarkan AIW, tanah tersebut didaftarkan dan diajukan perubahan sertifikat ke Badan Pertanahan Nasional (BPN) untuk diubah menjadi tanah wakaf atas nama nadhir (pengelola wakaf). Hal ini disebutkan dalam Undang-Undang RI Nomor 41 tahun 2004 tentang Wakaf (UU RI No. 41/2004), dan Peraturan Pemerintah RI Nomor 42 tahun 2006 tentang Pelaksanaan Undang-undang RI Nomor 41 tahun 2004 tentang Wakaf (PP RI No. 42/ 2006).

Ikrar wakaf harus dituangkan dalam AIW untuk mencegah terjadinya sengketa yang disebabkan tidak jelasnya status dan kedudukan wakaf, baik antara wakif atupun ahli warisnya dengan nazhir ataupun antara keluarga wakif dengan masyarakat umum. AIW menjadi bukti 
otentik wakaf apabila terjadinya sengketa dalam kasus di mana setelah wakif meninggal dunia, ahli warisnya tidak mengakui dan meminta kembali wakaf yang telah dilakukan. Selain itu, AIW juga untuk melindungi dan menjamin kesinambungan, kelestarian dan perkembangan benda wakaf itu sendiri.

Namun dalam praktek masih terdapat pelaksanaan wakaf yang dilakukan tidak memenuhi ketentuan perundang-undangan seperti yang terdapat di Kecamatan Wiradesa Kabupaten Pekalongan. Benda wakaf yang ada di Kecamatan Wiradesa umumnya berupa tanah dan bangunan dan mayoritas belum memiliki Akta Ikatan Wakaf ( AIW) dan sertifikat sebagai tanah wakaf. Jumlah benda wakaf cukup besar dan banyak yang lokasinya strategis. Berangkat dari sinilah penting untuk dilakukan penelitian tentang upaya perlindungan hukum terhadap harta benda wakaf sebagai aset publik di Kecamatan Wiradesa Kabupaten Pekalongan.

Permasalahan dalam penelitian ini adalah; 1) Bagaimanakah potensi harta benda wakaf di Kecamatan Wiradesa Kabupaten Pekalongan? 2) Bagaimanakah upaya perlindungan hukum terhadap harta benda wakaf sebagai aset publik di Kecamatan Wiradesa Kabupaten Pekalongan?

Tujuan penelitian ini adalah; 1) Mendeskripsikan potensi harta benda wakaf di Kecamatan Wiradesa Kabupaten Pekalongan. 2) Merumuskan upaya perlindungan hukum terhadap harta benda wakaf sebagai aset publik di Kecamatan Wiradesa Kabupaten Pekalongan.

Berdasarkan latar belakang, permasalahan dan tujuan penelitian, penelitian ini urgent untuk: 1) Hasil penelitian menjadi informasi tentang realitas pelaksanaan wakaf di masyarakat bagi pihak terkait, dalam hal ini Kantor Urusan Agama setempat, Kantor Kementerian Agama setempat, Pemerintah Daerah setempat, Majelis Ulama Indonesia setempat, dan Badan Wakaf Indonesia. 2) Dari hasil penelitian ini dapat dirumuskan upaya perlindungan hukum terhadap harta benda wakaf yang merupakan aset publik.

\section{Pengaturan wakaf di Indonesia}

Wakaf merupakan bagian dalam ajaran agama Islam yang memiliki peran penting dalam perkembangan Islam. Wakaf juga memiliki peranan penting dalam meningkatkan peradaban umat Islam. Lembaga-lembaga pengelola wakaf dapat berfungsi sebagai tempat penyebaran ilmu dan budaya, memberikan ruang bagi ulama, para ahli hukum Islam dan budayawan untuk 
mengembangkan keilmuan dan keahliannya. Wakaf pada masa Dinasti Islam telah berperan dalam memajukan lembaga pendidikan. Semua fasilitas pendidikan dapat dipenuhi dengan wakaf. Banyak lembaga pendidikan yang memberikan pendidikan gratis. Guru dan tenaga pengajar memperoleh gaji dari hasil keuntungan pengelolaan wakaf (Furqon, 2012: 45).

Wakaf berasal dari kata waqafa, sinonim kata habasa yang artinya berhenti, diam di tempat, atau menahan (Sabiq, 1995: 317). Secara istilah, para ulama berbeda pendapat tentang arti wakaf, namun maksudnya sama yaitu istilah untuk menunjuk suatu perbuatan hukum melepaskan milik/aset pribadi untuk kepentingan keagamaan dan kemasyarakatan (Hamzani, 2015: 51). Menurut UU RI No. 41/2004 Pasal 1 ayat (1); "wakaf adalah perbuatan hukum wakif untuk memisahkan dan/atau menyerahkan sebagain harta benda miliknya untuk dimanfaatkan selamanya atau untuk jangka waktu tertentu sesuai dengan kepentingannya guna keperluan ibadah dan/atau kesejahteraan umum menurut syari'at”.

Perbuatan hukum wakaf sah apabila memenuhi unsur-unsur rukun wakaf, yaitu: 1) Orang yang wakaf (waqif), 2) Harta yang diwakafkan, 3) Tujuan wakaf atau peruntukkan wakaf (mauquf 'alaihi), 4) Ikrar wakaf (sighat) (Al-Khatib, t.th.: 81). Menurut UU RI No. 41/2004 Pasal 6, wakaf dilaksanakan dengan memenuhi unsur sebagai berikut: a) Wakif. b) Nazhir (pengelola wakaf). c). Harta benda wakaf. d) Ikrar wakaf. e) Peruntukkan wakaf. f) Jangka waktu wakaf. Pasal 21 ayat (1) menyebutkan bahwa ikrar wakaf dituangkan dalam akta ikrar wakaf.

Harta yang diwakafkan harus milik sah orang yang mewakafkannya. Syarat sahnya pelaksanaan pendaftaran wakaf tanah hak milik adalah syarat materiil dan syarat formal. Syarat materiil berkaitan dengan pihak wakif dan nazhir dalam pelaksanaan wakaf tanah hak milik. Sedangkan syarat formal adalah wakaf tanah hak milik harus dibuktikan dengan AIW yang dibuat oleh PPAIW. Sebagai tanda bukti adanya pendaftaran wakaf tanah hak milik adalah diterbitkan sertipikat wakaf tanah hak milik oleh Kepala Kantor Pertanahan Kabupaten/Kota yang wilayah kerjanya meliputi letak tanah yang bersangkutan (Santoso, 2014: 79). Setelah diwakafkan oleh wakif, pemilikan harta beralih menjadi milik publik dan manfaatnya menjadi hak mauquf 'alaih, yaitu orang-orang yang berhak memperoleh hasil harta wakaf. Setelah wakif selesai mengucapkan ikrar wakaf seketika itu juga pemilikan harta lepas dari tangannya dan kembali menjadi milik Allah Swt., untuk kepentingan masyarakat sesuai peruntukkan wakaf (Usman, 2009: 88). 
Penerima dan pengelola wakaf dalam UU RI No. 41/2004 disebut ną̧hir baik perorangan maupun badan hukum. Ną̧birinilah yang mengelola dan mengurus harta benda wakaf tersebut. Berfungsi atau tidaknya wakaf tergantung dari pengelolaan. Nadhir berhak mengambil keuntungan dalam pengelolaan wakaf maksimal 10 persen dari keuntungan sebagai imbalan menjalankan fungsi kepengurusan dan kepengelolaan. Idealnya wakaf dikelola oleh naz̧bir professional, orang yang pekerjaannya fokus mengelola wakaf bukan sebagai pekerjaan sampingan.

\section{Akta ikrar wakaf sebagai bukti otentik perbuatan hukum wakaf}

PP RI No. 42/2006 Pasal 1 ayat (6) menyebutkan bahwa Akta Ikrar Wakaf (AIW) yang dibuat oleh Pejabat Pembuat Akta Ikrar Wakaf (PPAIW) adalah bukti pernyataan kehendak wakif untuk mewakafkan harta benda miliknya guna dikelola naz̧hir sesuai dengan peruntukan yang dituangkan dalam bentuk akta. Ayat (8) menyebutkan bahwa PPAIW adalah pejabat yang berwenang yang ditetapkan oleh menteri untuk membuat AIW. PPAIW dijabat oleh Kepala Kantor Urusan Agama (KUA) Kecamatan setempat. Sedangkan PPAIW untuk benda wakaf bergerak berupa uang adalah Pejabat Lembaga Keuangan Syariah paling rendah setingkat Kepala Seksi (Usman, 2009: 88).

Pembuatan AIW benda bergerak selain uang wajib memenuhi persyaratan dengan menyerahkan bukti pemilikan benda bergerak selain uang. Seperti pembuatan AIW benda tidak bergerak berupa tanah milik, maka wajib memenuhi persyaratan dengan menyerahkan sertifikat hak atas tanah yang bersangkutan atau tanda bukti pemilikan lain. AIW dibuat oleh PPAIW paling sedikit memuat:1) Nama dan identitas wakif. 2) Nama dan identitas nazhir. 3) Nama dan identitas saksi. 4) Data dan keterangan benda wakaf. 5) Peruntukan benda wakaf. 6) Jangka waktu wakaf.

Tata cara pembuatan AIW antara lain: 1) PPAIW meneliti kelengkapan persyaratan administrasi perwakafan dan keadaan fisik benda wakaf. 2) Pelaksanaan ikrar wakaf dan pembuatan AIW dianggap sah apabila dilakukan dalam Majelis Ikrar Wakaf. 3) AIW yang telah ditandatangani oleh wakif, nazhir, 2 (dua) orang saksi, dan/atau mauquf alaih disahkan oleh PPAIW. 4) Salinan AIW disampaikan kepada: a) wakif, b) nazhir, c) mauquf alaih, d) Kantor Pertanahan Kabupaten/Kota dalam hal benda wakaf berupa tanah, e) Instansi 
berwenang lainnya dalam hal benda wakaf berupa benda tidak bergerak selain tanah atau benda bergerak selain uang. Setelah dibuatkan AIW, menurut Pasal 32 UU RI No. 41/ 2004, PPAIW atas nama naz̧hir mendaftarkan benda wakaf kepada instansi yang berwenang paling lambat 7 (tujuh) hari kerja sejak AIW ditandatangani. Selanjutnya PPAIW menyerahkan: 1) Salinan AIW. 2) Surat-surat dan/atau bukti-bukti kepemilikan dan dokumenterkait lainnya.

Wakaf tanah hak milik harus memenuhi ketentuan yang terdapat dalam Peraturan Pemerintah RI Nomor 24 Tahun 1997 tentang Pendaftaran Tanah (PP RI No. 24/1997), yaitu: 1) Wakaf tanah hak milik termasuk salah satu objek pendaftaran tanah yang ditetapkan. 2) Pendaftaran wakaf tanah hak milik memenuhi tujuan pendaftaran tanah yang ditetapkan. 4) Pendaftaran wakaf tanah hak milik termasuk pendaftaran tanah secara sporadik yang bersifat individual. 5) Pendaftaran wakaf tanah hak milik termasuk kegiatan pendaftaran tanah untuk pertama kali. 6) Pendaftaran wakaf tanah hak milik membutuhkan peran PPAIW untuk membuat AIW. 7) Pendaftaran wakaf tanah hak milik menghasilkan tanda bukti hak berupa sertipikat tanah wakaf (Santoso, 2014: 77-78).

Tugas dankewajiban PPAIW adalah: 1) Meneliti kehendak wakif, tanah yang hendak diwakafkan, surat-surat bukti pemilikan, dan syarat-syarat wakif serta ada tidaknya halangan hukum bagi wakif untuk melepaskan hak atas tanahnya; 2) Meneliti dan mengesahkan susunan nazhir, atau perubahan susunan nazhir apabila ada perubahan; 3) Meneliti saksi-saksi ikrar wakaf; 4) Menyaksikan pelaksanaan ikrar wakaf dan ikut menandatangani formulir ikrar wakaf bersama-sama dengan saksi-saksi; 5) Membuat AIW rangkap tiga dan salinannya sesaat setelah pelaksanaan ikrar wakaf; 6) Menyimpan lembar pertama AIW, melampirkan lembar kedua pada surat permohonan pendaftaran yang dikirimkan kepada Bupati/Walikota c.q. Kantor Badan Pertanahan Nasional dan lembar ketiga dikirim kepada Pengadilan Agama yang mewilayahi tanah wakaf tersebut; 7) Menyampaikan salinan AIW dan salinannya selambat-lambatnya satu bulan sejak dibuat; 8) Menyampaikan salinan AIW 4 (empat) lembar, lembar pertama kepada wakif, lembar kedua kepada nazhir, lembar ketiga kepada Kantor Kementerian Agama, lembar keempat kepada Kepala Desa yang mewilayahi tanah wakaf tersebut. 9) Menyelenggarakan Daftar AIW. 10) Menyimpan dan memelihara AIW dan Daftar AIW yang dibuatnya dengan baik. 11) Mengajukan permohonan atas nama nazhir yang bersangkutan kepada Kepala Kantor Badan Pertanahan Kabupaten/Kota setempat 
untuk mendaftar perwakafan tanah milik yang bersangkutan, selambat-lambatnya dalam waktu 3 (tiga) bulan sejak dibuat AIW.

AIW yang dikeluarkan PPAIW merupakan satu-satunya alat bukti otentik yang dapat membuktikan telah dilakukannya perbuatan hukum wakaf. AIW menurut hukum diakui secara sah oleh negara, sehingga dapat digunakan untuk membuktikan adanya pemberian wakaf. Pemberian wakaf yang dilakukan hanya secara lisan atau di bawah tangan tidak sah menurut hukum. Wakaf di bawah tangan merupakan praktek wakaf yang dilakukan oleh para pihak sendiri baik secara lisan maupun tertulis tanpa disertai dengan pembuatan AIW oleh PPAIW. Berdasarkan Pasal 1847 Kitab Undang-Undang Hukum Perdata, akta dibawah tangan adalah akta yang dibuat oleh para pihak yang dilakukan tidak di hadapan pejabat umum. Pejabat umum dalam perbuatan hukum wakaf adalah PPAIW/Kepala KUA.

\section{Perlindungan hukum terhadap perbuatan hukum wakaf}

Indonesia merupakan negara hukum seperti disebutkan dalam Undang-Undang Dasar Negara Republik Indonesia (UUD NRI) tahun 1945. Negara Indonesia adalah negara hukum yang demokrasi (democratische rechtstaat), dan demokrasi yang berdasarkan atau hukum (constitutional democracy). Paham negara hukum seperti tercantum dalam ketentuan Pasal 1 Ayat (3) berkaitan dengan negara kesejahteraan (welfare state). Hukum menjadi penentu sesuai prinsip nomokrasi dan doktrin 'the rule of law, and not man. Hukum mempunyai kedudukan tertinggi (supremacy of law), adanya persamaan dalam hukum dan pemerintah (equality before the law), dan berlaku asas legalitas dalam segala bentuk dan praktek (due process of law) (Ridlwan, 2012: 143-144).

Tujuan negara hukum adalah untuk menyelenggarakan dan menjaga ketertiban hukum agar semua aspek kehidupan bernegara berjalan menurut hukum. Negara hukum menjamin adanya tertib hukum dalam masyarakat. Tujuan negara Indonesia sebagai negara hukum juga menciptakan masyarakat adil dan makmur baik material maupun spiritual. Konsep rechtsstaat bagi Indonesia dapat dikategorikan sebagai negara kesejahteraan (verzorgingsstaat), negara yang makmur secara material dan spiritual. (Sayuti, 2011: 104).

Perlindungan hukum dalam negara hukum menjadi sangat esensial terhadap subyek dan obyek hukum. Hukum sebagai aturan bersama untuk tiap-tiap warga negara dan mengatur 
semua aspek bernegara. Hubungan antara sesama subyek hukum akan terjadi suatu hubungan timbal balik antara warga dengan warga, dan warga dengan masyarakat yang diwakili oleh negara yang akan melahirkan hak dan kewajiban.

Menurut Hadjon (1987: 32) perlindungan hukum adalah memberikan pengayoman kepada hak yang dirugikan orang lain. Perlindungan hukum sebagai upaya hukum untuk memberikan rasa aman terhadap subyek maupun obyek hukum. Negara hukum menjadikan instrument perlindungan hukum sebagai pengayoman terhadap subyek dan obyek hukum dengan sarana preventif dan represif. Pengayoman memberikan jaminan bahwa hukum dapat memberikan suatu keadilan, kepastian dan kemanfaatan.

Berkaitan dengan aset, perlindungan hukum berarti perlindungan terhadap aset tersebut agar dapat digunakan dan tidak disalahgunakan. Perlindungan hukum terhadap aset wakaf berarti sarana yang diberikan hukum untuk dapat melindungi aset tersebut. Sarana hukum yang terhadap wakaf adalah bahwa perbuatan hukum wakaf memiliki bukti hukum. Melaksanakan wakaf sesuai dengan aturan hukum, yaitu pelaksanaan wakaf dituangkan dalam AIW agar terlindunggi secara hukum.

Akibat hukum dari pelaksanaan wakaf yang sesuai dengan hukum adalah; 1) Kepastian hukum atas harta yang diwakafkan. 2) Dapat membuat rasa aman bagi orang yang wakaf bahwa proses pelaksanaan wakaf telah sesuai dengan aturan syari'ah dan perundang-undangan. 3) Kepastian kekekalan manfaat benda wakaf sesuai dengan tujuan dan sasaran wakaf dapat terjaga. 4) Sebagai antisipasi apabila terjadi sengketa wakaf di kemudian hari (Hermit, 2007: 5).

\section{Metode penelitian}

Jenis penelitian ini adalah penelitian lapangan (feild research) atau studi kasus, lokasi penelitiannya di Kecamatan Wiradesa Kabupaten Pekalongan. Pendekatan yang digunakan adalah pendekatan sosiologis, sehingga termasuk sosio-legal research (penelitian hukum sosiologis) dan dalam lingkup penelitian hukum empiris. Pendekatan sosiologis dalam penelitian hukum merupakan pendekatan yang obyek telaahnya hukum dikaitkan dengan realitas-empiris (solen vs sein). (Soerjono Soekanto, dkk., 1988: 9). Hukum sangat berkaitan dengan perilaku masyarakat dan selalu berinteraksi dengan aspek-aspek politik, sistem sosial, ekonomi, budaya dan agama (Tamanaha, 2006: 34). Pengumpulan data melalui observasi dan wawancara, 
setelah data terkumpul dilakukan analisis induksi-itepretasi-konseptualisasi model interaktif Mattew B. Miles dan A. Michael Huberman (1992: 22) yang meliputi 3 (tiga) kegiatan; reduksi, penyajian dan penarikan kesimpulan.

\section{Potensi harta benda wakaf di kecamatan Wiradesa kabupaten Pekalongan}

Masyarakat di kecamatan Wiradesa kabupaten Pekalongan telah lama mempraktekkan wakaf sebagai penunjang sarana ibadah, pendidikan, dan sosial. Pelaksanaan wakaf dilakukan secara tradisional atas dasar saling percaya dan penyerahannya secara lisan. Masyarakat yang mewakafkan hartanya karena merasa memiliki kelebihan ekonomi dan berusia lanjut dengan motivasi sebagai amal jariah (amal yang pahalanya akan mengalir terus). Adapula yang pelaksanaannya melalui wasiat.

Benda wakaf yang ada di Kecamatan Wiradesa cukup banyak, yaitu sejumlah 349, tersebar di 16 Desa dan Kelurahan. Rinciannya sebagai berikut:

\section{Tabel 1}

\section{Benda Wakaf di Kecamatan Wiradesa}

\begin{tabular}{clc}
\hline No. & Desa/Keluarahan & Jumlah \\
\hline 1 & Kadipaten & 27 \\
2 & Delcotukang, & 21 \\
3 & Karangjati & 25 \\
4 & Petukangan & 23 \\
5 & Warukidul & 26 \\
6 & Wiradesa & 24 \\
7 & Warulor & 26 \\
8 & Bondansari & 26 \\
9 & Kampil & 16 \\
10 & Kemplong & 17 \\
11 & Kauman & 25 \\
12 & Gumawang & 26 \\
13 & Kepatihan & 14 \\
14 & Mayangan & 24 \\
15 & Pelkuncen & 27 \\
16 & Bener & 29 \\
\hline
\end{tabular}


Wakif (orang yang mewakafnya hartanya) semua perorangan. Sedangkan nazhir (pengelola wakaf) umumnya badan hukum organisasi kemasyarakatan, yayasan, dan sebagain kecil kelompok masyarakat seperti pengurus masjid.

Penggunaan benda wakaf mayoritas untuk sarana peribadatan yaitu mushalla dan masjid, selebihnya untuk lembaga pendidikan. Secara lebih rinci penggunaan benda wakaf dapat terlihat dalam tabel berikut:

Tabel 2

Peruntukan dan Penggunaan Benda wakaf

\begin{tabular}{clcl}
\hline No. & \multicolumn{1}{c}{ Penggunaan } & Jumlah & \multicolumn{1}{c}{ Keterangan } \\
\hline 1. & Masjid & 65 & \\
2 & Langgar/Mushalla & 193 & \\
3 & Lembaga & 78 & TK/TPQ/SD/MI/SMP/MTs/ \\
& Pcndidikan & & MA/SMA/SMK/Diniyah/Pondok \\
& & & Pesantren \\
4 & Lainnya & 13 & Balai Pengobatan/Kantor, Dsb. \\
\hline & Jumlah & 349 & \\
\hline
\end{tabular}

Banyaknya jumlah benda wakaf belum berdampak secara ekonomi untuk memmbiayai kegiatan keagamaan, pendidikan dan sosial. Hal ini karena nadhir mengelola wakaf hanya sebagai pekerjaan sampingan, bukan nadhir profesional. Banyak benda wakaf yang potensial dapat dikembangkan seperti tanah-tanah kosong di sekitar masjid/mushala, madrasah, tidak dimanfaatkan secara maksimal. Apabila dimanfaatkan dengan baik, dapat berkembangkan dan dapat diberdayakan secara ekonomis guna pembiyaan masjid, mushalla maupun lembaga pendidikan. Justru yang terjadi para nadhir membebani masyarakat sekitar untuk berpartisipasi membiayai perawan masjid/mushala ataupun lembaga pendidikan. Tidak sendikit tanahtanah wakaf tersebut dibiarkan kosong, dan ada yang dijadikan tempat pembuangan sampah ilegal.

Mayoritas pelaksanaan ikrar wakaf tidak di hadapan PPAIW/Kepa KUA sehingga tidak dituangkan AIW. Data yang tercatat di KUA hasil pantauan dan laporan masyarakat umum. Rincian tentang data benda yang memiliki AIW/APAIW dan tidak memiliki dapat terlihat dalam tabel berikut: 
Perlindungan hukum terhadap harta benda wakaf ... (Achmad Irwan Hamzani dan Mukhidin)

Tabel 3

Prosentase Benda Wakaf yang Sudah Mempunyai AIW/APAIW

\begin{tabular}{cccc}
\hline No. & Benda Wakaf & Jumlah & Prosentase \\
\hline 1 & Mempunyai $\Lambda \mathrm{IW} / \Lambda \mathrm{P} \Lambda \mathrm{IW}$ & 81 & $34 \%$ \\
2 & Belum Mernpunyai AIW/APAIW & 268 & $66 \%$ \\
\hline \multicolumn{2}{c}{ Jumlah } & $\mathbf{3 4 9}$ & $\mathbf{1 0 0 \%}$ \\
\hline
\end{tabular}

Kesadaran masyarakat di Kecamatan Wiradesa untuk melaksanakan wakaf sesuai dengan peraturan perundang-undangan masih rendah. Berdasarkan UU RI No. 41/2004, bahwa ikrar wakaf wajib dituangkan dalam AIW, dilakukan di hadapan PPAIW, atau melaporkan ke KUA untuk dibuatkan AIW/APAIW, yang selanjutnya dilakukan pendaftaran, proses sertifikasi dan diumumkan ke publik yang tata caranya diatur dalam peraturan perundangundangan.

Mayoritas benda wakaf di Kecamatan Wiradesa berupa tanah milik dan bangunan. Namun yang sudah bersertifikat sebagai tanah wakaf sangat sedikit. Umumnya benda wakaf belum bersertifikat wakaf dan bersertifikat bukan sebagai tanah wakaf, seperti terlihat dalam tabel berikut:

Tabel 4

Prosentase Sertifikasi Benda wakaf

\begin{tabular}{ccccc}
\hline No. & Benda wakaf & & Jumlah & Prosentase \\
\hline 1 & Tanah Wakaf yang Bcrscrtifikat Wakaf & & 2 & $1 \%$ \\
2 & Tanah Wakaf yang Bersertifikat & Bukan Wakaf & & \\
& (Perorangan) & 62 & $26 \%$ \\
3 & T'anah Wakaf yang 'lidak Bersertifikat & 285 & $73 \%$ \\
\hline \multicolumn{6}{c}{ Jumlah } & 349 & $\mathbf{1 0 0 \%}$ \\
\hline
\end{tabular}

Tanah wakaf yang bersertifikat sebagai tanah wakaf prosentasenya sangat kecil yaitu $1 \%$, bersertifikat bukan wakaf $26 \%$, dan tidak bersertifikat $73 \%$. Padahal sertifikasi wakaf sangat penting untuk melindungi potensi beralih kepemilikan dan penukaran.

Minat dan semangat masyarakat di Kecamatan Wiradesa untuk wakaf tidak didasari pemahaman tentang regulasi wakaf. Ada wakif yang beranggapan bahwa benda yang telah diwakafkan untuk selamanya, dia masih berhak atas wakaf tersebut. Demikian juga ahli 
waris wakif, ada yang menganggap bahwa mereka masih berhak terhadap benda yang telah diwakafkan orang tuanya. Nadhir juga harus meminta izin kepada mereka apabila hendak mengembangkan wakaf, atau sebatas hendak melakukan perawan apabila wakafnya berupa mushalla (Hasil wawancara dengan wakif, ahli waris wakif, dan nadhir Juni 2015).

Tokoh agama yang menjadi nadhir (pengelola wakaf) juga kurang memahami ketentuan wakaf seperti diatur dalam undang-undang. Wakaf dipandang sebabatas anjuran agama yang akan menjadi amal jâriyah (kebaikannya mengalir terus), tanpa memahami bagaimana ketentuan agar wakaf tersebut benar-benar menjadi amal jâriyah.

Wakaf memang identik dengan amal jâriyah. Benda wakaf yang dikeluarkan, sepanjang benda itu dimanfaatkan untuk kepentingan kebaikan maka selama itu pula orang yang wakaf mendapat pahala secara terus-menerus meskipun telah meninggal dunia. Wakaf tidak akan valid sebagai amal jâriyah kecuali setelah benar-benar pemiliknya menyatakan aset yang diwakafkannya menjadi aset publik dan dibekukan. Wakaf juga tidak akan bernilai amal jâriyah sampai benar-benar didayagunakan secara produktif dan bermanfaat tanpa menggerus habis aset pokok wakaf.

Ada nadhir yang menganggap bahwa benda wakaf tersebut telah menjadi miliknya, karena sudah diserahkan oleh wakif. Mereka tidak memahami bahwa posisi nazhir wakaf hanya sebagai pengelola saja, bukan sebagai pemilik, dan pemilik wakaf adalah publik/ masyarakat secara umum. Pemahaman seperti ini berpotensi beralihnya benda wakaf menjadi hibah. Padahal ada perbedaan antara wakaf dengan hibah, yaitu penerima wakaf bukan pemilik dari wakaf. Pemberian wakaf merupakan pembekuan aset menjadi milik Allah Swt. yang lepas kepemilikanya dari wakif, nadhir maupun pihak lainnya (Mustaffa dan Muda, 2014: 46). Sedangkan hibah, penerima hibah adalah pemilik dari hibah tersebut. Tidak sedikit pula benda wakaf khususnya yang dikelola oleh kelompok telah beralih kepemilikannya ke ahli waris nadhir.

Menurut Kepala KUA Kecamatan Wiradesa dan Pejabat Kantor Kementerian Agama Kabupaten Pekalongan, program sosialisasi, pembinaan terhadap nadhir dan sertifikasi wakaf sebenarnya ada di Kantor Kementerian Agama dan KUA, namun karena keterbatasan anggaran dan SDM, tidak dapat menjangkau semua nadhir wakaf apalagi masyarakat umum. Bahkan menurut MB, Kepala KUA Kecamatan Wiradesa, KUA mengalami kesulitan untuk 
mendata dan mengaudit benda wakaf dikaranakan terbatasnya jumlah SDM serta tidak adanya laporan keadaan benda wakaf oleh nadzhir.

Rendahnya praktek wakaf yang sesuai dengan prosedur juga karena sosialisasi regulasi wakaf yang sangat kurang dan kecilnya anggaran sertifikasi yang dimiliki KUA maupun Kemenag. Dampaknya pada akuntabilitas pengelolaan wakaf, dan membuat nadhir tidak memahami prosedur wakaf, mulai dari pendaftaran, pengurusan sertifikat sampai pada pengembangan benda wakaf. Minimnya biaya APBN untuk sertifikasi wakaf membuat nadhir kurang berminat untuk melegalkan harta wakaf yang dikelolanya. Padahal sertifikasi wakaf merupakan hal yang sangat penting.

Banyaknya wakaf yang tidak memiliki AIW/APAIW dan belum bersertifikat sebagai wakaf, menunjukkan bahwa akuntabilitas regulator dalam meningkatkan sertifikasi wakaf masih kurang. Kinerja regulator dalam membantu masyarakat untuk sertifikasi wakaf masih belum optimal. Seharusnya semua harta wakaf sudah tersertifikasi, sehingga potensi beralihnya wakaf untuk kepentingan non wakaf dapat diantisipasi (Huda, dkk., 2014: 489).

Menumbuhkembangkan kesadaran hukum memang tidak mudah. Diperlukan perangkat pendukung seperti materi hukum, keteladanan regulator, dan sosialisasi agar terbentuk budaya sadar hukum. Budaya sadar hukum merupakan dimensi penting karena budaya hukum merupakan cita-cita dan harapan terhadap hukum. Tumbuh kuatnya budaya hukum akan menentukan efektifitas hukum di masyarakat (Purwaningsih, 2012: 8-9).

Agar pelaksanaan wakaf sesuai dengan ketentuan hukum perlu diadakan sosialisasi, pembiayaan sertifikasi, pembinaan bahkan pendampingan kepada wakif dan nadhir. Pelaksanaan wakaf sesuai dengan hukum akan menjamin bahwa amalan wakaf sesuai dengan ketentuan syari'at, sehingga konsep amal jâriyah (kebaikannya mengalir terus) yang melekat pada wakaf terpenuhi karena sebagai aset publik terlindungi secara hukum. Apabila benda wakaf telah beralih dari sisi kepemilikan maupun kemanfaatan, maka amal jâriyah tidak tercapai.

\section{Perlindungan hukum harta wakaf sebagai aset publik}

Harta benda wakaf di Kecamatan Wiradesa rentan penyimpangan seperti diminta kembali oleh ahli waris wakif, berpindah kepemilikan wakaf menjadi hak milik nadhir secara turun 
temurun, dialihkan untuk keperluan pribadi maupun kelompok. Potensi penyimpangan harus diproteksi, karena benda wakaf merupakan aset publik. Diperlukan sarana hukum untuk melindungi benda wakaf dari potensi penyimpangan.

Secara hukum, AIW yang dikeluarkan PPAIW merupakan satu-satunya alat bukti otentik yang dapat membuktikan telah dilakukannya perbuatan hukum wakaf. AIW menurut hukum diakui secara sah oleh negara, sehingga dapat digunakan untuk membuktikan adanya pemberian wakaf. Pemberian wakaf yang dilakukan hanya secara lisan atau di bawah tangan tanpa pembuatan AIW yang dikeluarkan oleh PPAIW tidak sah menurut hukum.

Pembuatan AIW dilakukan setelah wakif mengikrarkan dan menyerahkan harta yang diwakafkan. Walaupun ikrar wakaf dilakukan secara tertulis, namun AIW harus tetap dibuat karena sebagai alat bukti sahnya perbuatan hukum wakaf. Selain AIW, adapula APAIW. Perbedaan AIW dan APAIW adalah waktu pelaksanaan wakaf dan pembuatan akta. Pembuatan AIW untuk tanah-tanah yang diwakafkan setelah berlakunya Peraturan Pemerintah RI Nomor 28 tahun 1977 tentang Perwakafan Tanah Milik (PP RI No. 28/1977), dan wakaf yang pada waktu pembuatan akta wakif masih hidup. Sedangkan APAIW dibuat untuk benda tanah yang diwakafkan sebelum berlakunya PP RI No. 28/1977, dan dan wakaf yang pada waktu pembuatan akta wakifnya telah meninggal dunia. AIW maupun APAIW dibuat oleh PPAIW, yaitu Kepala KUA setempat. Kedudukan Kepala KUA sebagai pembuat AIW maupun APAIW sama dengan kedudukan camat dan notaris yang menjabat sebagai Pejabat Pembuat Akta Tanah (PPAT).

Peran PPAIW dalam pelaksanaan wakaf sangat penting. Berdasarkan UU RI No. 41/ 2004 maupun PP RI No. 42/2004 dalam melaksanaan wakaf, wakif harus mengikrarkan kehendaknya secara jelas dan tegas kepada nazhir di hadapan PPAIW, disaksikan oleh sekurangkurangnya 2 (dua) orang saksi dan dituangkan dalam bentuk AIW. Ikrar yang disampaikan oleh wakif tersebut berisikan pernyataan kehendak dari wakif untuk mewakafkan tanah miliknya.

Wakaf di bawah tangan merupakan praktek wakaf yang dilakukan oleh para pihak sendiri baik secara lisan maupun tertulis tanpa disertai dengan pembuatan AIW oleh PPAIW. Berdasarkan Pasal 1847 Kitab Undang-Undang Hukum Perdata, akta di bawah tangan adalah akta yang dibuat oleh para pihak yang dilakukan tidak di hadapan pejabat umum. 
Pejabat umum dalam perbuatan hukum wakaf adalah PPAIW/Kepala KUA. Pelaksanaan wakaf di bawah tangan dapat menimbulkan masalah di kemudian hari yang berkaitan dengan status kepemilikan tanah wakaf tersebut seperti diambil alih oleh ahli waris wakif, maupun berpindah kepemilikan menjadi milik pribadi nadhir, ahli waris nadbir maupun pihak lain. Apabila terjadi sengketa, misalnya ahli waris wakif menyangkal bahwa pewarisnya telah mewakafkan tanah kepada nadhir, maka nadhir tidak dapat mempertahankan tanah wakaf tersebut.

Pemerintah telah mengadakan program sertifikasi tanah-tanah wakaf (pembuatan AIW / APAIW dan pembuatan sertifikat sebagai tanah wakaf) sejak terbitnya PP RI No. 28/1977. Selanjutnya pemerintah mengeluarkan Surat Keputusan Bersama Menteri Agama dan Kepala Badan Pertanahan Nasional Nomor 422 tahun 2004 dan Nomor 3/ SKB/ BPN/ 2004 tentang Sertifikasi Tanah Wakaf. Keputusan ini dikeluarkan dikarenakan masih banyaknya tanah wakaf di seluruh Indonesia yang belum bersertifikat, sehingga perlu dilakukan peningkatan sertifikatnya demi untuk tertib administrasi dan kepastian hak.

Walaupun program sertifikasi tanah wakaf telah diselenggarakan oleh pemerintah di mana pembuatan AIW/APAIW merupakan suatu keharusan, namun masih belum efektif. Masih masih banyak tanah-tanah wakaf yang belum dituangkan dalam AIW/APAIW dan belum disertifikatkan. Seperti di Kecamatan Wiradesa masih banyak benda wakat yang belum memiliki AIW/APAIW sebesar 66\%, dan belum memiliki sertifikat sebagai tanah wakaf sebesar $99 \%$.

Agar pemberian wakaf yang dilakukan secara lisan atau di bawah tangan di Kecamatan Wiradesa tetap diakui secara hukum, maka bentuk pengamanan yang dapat dilakukan adalah: Pertama, apabila wakif masih hidup bentuk pengamanannya dengan dibuatkan AIW oleh PPAIW. Kedua, apabila wakiftelah meninggal dunia bentuk pengamanannya dengan dibuatkan APAIW oleh PPAIW. Pelaporan adanya harta benda wakaf agar dibuatkan APAIW dapat dilakukan oleh masyarakat umum, tokoh masyarakat, ataupun kepala desa/kelurahan. Tidak menutup kemungkinan dalam pembuatan APAIW ahli waris wakif mengingkari adanya pemberian wakaf oleh wakif. Apabila hal ini terjadi, nadbir dapat mengajukan permohonan ithbat wakaf ke Pengadilan Agama. Penetapan Pengadilan Agama tersebut selanjutnya menjadi dasar permohonan sertifikat tanah. Setelah dibuatkan AIW/APAIW oleh PPAIW selanjutnya 
didaftarkan untuk dilakukan perubahan sertifikat ke Badan Pertanahan Kabupaten/ Kota. Sertifikat atas nama wakif dicoret dan diganti dengan atas nama nadhir dengan dibuatkan sertifikat wakaf.

Benda wakaf yang ada di Kecamatan Wiradesa didominasi oleh tanah milik. Sertifikasi tanah wakaf menjadi sangat penting untuk melindungi wakaf secara hukum. Tanah mempunyai arti sangat penting dalam kehidupan bermasyarakat dan bernegara. Seiring dengan perkembangan pesat dalam pembangunan di berbagai bidang, menjadikan kedudukan tanah sebagai modal yang paling utama dalam kehidupan masyarakat di Indonesia. Sertifikat tanah merupakan bukti kepemilikan terhadap suatu bidang tanah. Pemegang sertifikat hak atas tanah telah mendapat perlindungan hukum dan dijamin oleh undang-undang atas tanah yang dimilikinya. Apabila terjadi sengketa tanah, pemilik sertifikat tanah yang dimiliki kedudukan hukumnya sangat kuat.

Kaidah hukum yang dianut dalam hukum pertanahan nasional adalah bahwa setiap orang atau badan hukum melakukan suatu perbuatan hukum yang berupa pengalihan hak atas tanah, wajib dilakukan dihadapan pejabat yang berwenang untuk itu, guna mendapatkan akta sebagai bukti atau jaminan. Ketentuan tersebut untuk mendapatkan kepastian hukum dan kepastian hak atas tanah yang telah dialihkan tersebut. Ketentuan yang mengatur pendaftaran tanah dapat dilihat dalam Pasal 19 ayat (1) Undang-Undang RI Nomor 5 tahun 1960 tentang Peraturan Dasar Pokok-pokok Agraria dan Peraturan Pemerintah RI Nomor 24 Tahun 1997 tentang Pendaftaran Tanah.

Semua aspek hukum harus dituntaskan melalui sarana-sarana hukum. Negara hukum menempatkan semua persoalan kemasyarakatan dalam bingkai hukum. Fungsi hukum adalah melakukan usaha untuk menggerakkan masyarakat sesuai dengan cara-cara hukum (Daryanto, 2013: 505).

Hukum dibuat dan diterapkan dalam rangka menciptakan ketertiban, menegakkan keadilan, kemanfaatan, dan kepastian. Untuk mencapai tujuan tersebut maka norma-norma hukum harus ditegakkan. Penegakan hukum adalah proses dilakukannya upaya untuk tegaknya atau berfungsinya norma-norma hukum secara nyata sebagai pedoman perilaku dalam lalu lintas atau hubungan-hubungan hukum dalam kehidupan bermasyarakat dan bernegara. Hukum harus bisa ditegakkan agar dapat berfungsi dengan baik sehingga tujuan dari hukum 
tersebut dapat tercapai (Thamrin, 204: 50).

Berdasarkan tujuan-tujuan tersebut, hukum modern menekankan pada lima unsur yang menentukan hukum dapat dilaksanakan: 1) Kapasitas aturan-aturan, standar-standar, atau prinsip-prinsip hukum untuk memandu masyarakat dalam melaksanakan urusan-urusannya, dan masyarakat harus mengetahui hukum dan mematuhinya. 2) Agar hukum efektif rakyat harus diperintah oleh hukum dan mematuhinya (people should be ruled by law and obey it). 3) Hukum harus memungkinkan stabilitas, agar dapat memfasilitasi perencanaan dan mengkoordinasikan berbagai tindakan sepanjang waktu. 4) Supremasi otoritas terhadap siapun, pemerintah, penegak hukum, dan maupun masyarakat umum. 5) Pengadilan yang tidak memihak dan dilaksanakan sesuai prosedur yang jujur dan adil (Azhari, 2012: 496497).

Semua peraturan perundang-undangan yang mengatur tentang perwakafan tanah menegaskan perlunya sertifikasi untuk mendapatkan sertifikat tanah wakaf seperti disebutkan dalam UU RI No. 41/2004 dan PP RI No. 42/2006. Memang dalam kajian hukum Islam tidak terdapat dasar hukum yang mewajibkan agar tanah wakaf memiliki sertifikat wakaf. Namun terdapat anjuran untuk melakukan pencatatan sebagai bentuk upaya perlindungan hukum dan menghilangkan kebimbangan terhadap status benda wakaf. Pembuatan AIW/ APAIW yang selanjutnya dibuatkan sertifikat tanah wakaf pada pokoknya adalah untuk memperoleh jaminan, kepastian dan perlindungan hukum tentang tanah yang diwakafkan.

\section{Penutup}

Berdasarkan uraian diatas dapat disimpulkan bahwa harta benda wakaf di Kecamatan Wiradesa banyak yang tidak memiliki AIW ataupun. Wakaf yang mempunyai AIW atau APAIW 34\%, yang belum 66\%. Harta benda wakaf umumnya tanah dan bangunan, namun yang bersertifikat sebagai tanah wakaf hanya $1 \%$, bersertifikat tapi bukan sertifikat tanah wakaf $26 \%$ dan belum bersertifikat $73 \%$. AIW maupun APAIW merupakan bukti otentik perbuatan hukum wakaf. Wakaf yang yang tidak dibuatkan AIW maupun APAIW tidak memiliki kekuatan hukum dan rentang penyimpangan sehingga diperlukan sarana hukum untuk melindungi. Bentuk pengamanan yang dapat dilakukan yaitu; apabila wakif masih hidup bentuk pengamanannya dengan dibuatkan AIW, dan apabila wakif telah meninggal 
ljtihad, Jurnal Wacana Hukum Islam dan Kemanusiaan, Volume 16, No. 2, Desember 2016: 159-177

dunia dibuatkan APAIW oleh PPAIW. Setelah dibuatkan AIW/APAIW untuk benda wakaf berupa tanah milik selanjutnya didaftarkan untuk dilakukan perubahan sertifikat ke Badan Pertanahan Kabupaten/Kota menjadi sertifikat tanah wakaf.

\section{Daftar pustaka}

Al-Khatib, Muhammad al-Syarbini. al-Iqna: fi Hali Alfadi Abi Sija'. Indonesia: Daar Ihya alKitab al-Arabiyah, t.th.

Azhari, Aidul Fitriciada. "Negara Hukum Indonesia; Dekolonisasi dan Rekonstruksi Tradisi”, dalam Jurnal Ius Quia Iustum. Vol. 496, No. 4, (Oktober 2012): 489-505.

Dayanto. "Rekonstruksi Paradigma Pembangunan Negara Hukum Indonesia Berbasis Pancasila" dalam Jurnal Dinamika Hukum. Vol. 13, No. 3, (September 2013): 498-509.

Fikri, Dimas Fahmi dan Afif Noor. "Reformasi Hukum Wakaf di Indonesia; Studi terhadap Wakaf Hak Atas Kekayaan Intelektual”, dalam Jurnal Al-Abkam. Vol. 22, No. 1, (April 2012): 43-60.

Furqon, Ahmad. "Wakaf Sebagai Solusi Permasalahan Dunia Pendidikan di Indonesia", dalam Jurnal Hukum Islam. Vol. 10, No. 1, (Juni 2012): 35-52.

Hadjon, Philipus M. Perlindungan Hukum bagi Rakyat Indonesia. Surabaya: Bina Ilmu, 1987.

Hamzani, Achmad Irwan. Perkembangan Hukum Wakaf di Indonesia. Brebes: Diya Media Group, 2015.

Hermit, Herman, Cara Memperoleh Sertifikat Tanah Wakaf. Bandung: Mandar Maju, 2007.

Huda, Nurul, dkk. "Akuntabilitas sebagai Sebuah Solusi Pengelolaan Wakaf”, dalam Jurnal Akuntasi Multiparadigma (JAMAL). Vol. 5, No. 3, (Desember, 2014): 485-497.

Peraturan Pemerintah RI Nomor 28 tabun 1977 tentang Perwakafan Tanah Milik.

Peraturan Pemerintah RI Nomor 42 tahun 2006 tentang Pelaksanaan Undang-undang RI Nomor 41 tahun 2004 tentang Wakaf.

Undang-undang RI Nomor 41 tahun 2004 tentang Wakaf.

Undang-undang RI Nomor 5 tahun 1960 tentang Peraturan Dasar Pokok-pokok Agraria.

Kitab Undang-undang Hukum Perdata.

Peraturan Pemerintah RI Nomor 24 tentang Pendaftaran Tanah.

Miles, Mattew B., dan A. Michael Huberman. Analisis Data Kualitatif. Jakarta: UI Press, 1992.

Mustaffa, Najibah, dan Mohd Zamro bin Muda. "Pengurusan Wakaf Pendidikan di Institusi Pengajian Tinggi Malaysia: Satu Sorotan Literatur", dalam Internasional Journal of Islamic and Civilizational Studies. Vol. 1, No. 1, (Desember, 2014): 42-57. 
Purwaningsih, Endang. "Perlindungan Hukum terhadap Kekayaan Intelektual Warisan Bangsa sebagai Implikasi Yuridis Nilai-nilai Kebangsaan Menuju Ketahanan Nasional”, dalam Jurnal Negarawan. Vol. 26, (Desember 2012): 1-14.

Ridlwan, Zulkarnain. "Negara Hukum Indonesia Kebalikan Nachtwachterstaat", dalam Jurnal Fiat Justitia. Vol. 5, No. 2, (Mei-Agustus 2012): 141-152.

Sabiq, Sayid. Fiqh Sunnah.Juz III, Mesir: Daar al-Fatih Li al-'Ilam al-Arabi, 1995.

Sayuti. "Konsep Rechtsstaat dalam Negara Hukum Indonesia; Kajian terhadap Pendapat Azhari”, dalam Jurnal Nalar Figh. Vol. 4, Nomor 2, (Desember 2011): 81-105.

Santoso, Urip. "Kepastian Hukum Wakaf Tanah Hak Milik", dalam Jurnal Perspektif. Vol. XIX, No. 2, (Mei, 2014): 71-80.

Soekanto,Soerjono, dkk. Pendekatan Sosiologi terhadap Hukum. Jakarta: PT. Bina Aksara, 1988.

Tamanaha, Brian Z. A General Jurisprudensce of Law and Society.New York: Oxford University Press, 2006.

Thamrin, Husni. "Penegakan Hukum di Indonesia dalam Perspektif Negara Hukum", dalam Jurnal Proghresif. Vol. 11, No. 32, (Agustus 2014): 49-55.

Usman, Rachmat. Hukum Perwakafan di Indonesia. Jakarta: Sinar Grafika, 2009. 